Comparative Philosophy Volume 3, No. 1 (2012): 58-73

Open Access / ISSN 2151-6014

www.comparativephilosophy.org

\title{
HOW TO AVOID SOLIPSISM WHILE REMAINING AN IDEALIST: LESSONS FROM BERKELEY AND DHARMAKĪRTI
}

\author{
JEREMY E. HENKEL
}

\begin{abstract}
This essay examines the strategies that Berkeley and Dharmakirti utilize to deny that idealism entails solipsism. Beginning from similar arguments for the non-existence of matter, the two philosophers employ markedly different strategies for establishing the existence of other minds. This difference stems from their responses to the problem of intersubjective agreement. While Berkeley's reliance on his Cartesian inheritance does allow him to account for intersubjective agreement without descending into solipsism, it nevertheless prevents him from establishing the existence of other finite minds. I argue that Dharmakirti, in accounting for intersubjective agreement causally, is able to avoid Berkeley's shortcoming. I conclude by considering a challenge to Dharmakirti's use of inference that Ratnakirti, a Buddhist successor of Dharmakirti, advances in his "Disproof of the Existence of Other Minds" and briefly exploring a possible response that someone who wants to advocate an idealist position could give.
\end{abstract}

Keywords: Berkeley, Dharmakīrti, Ratnakīrti, idealism, solipsism, philosophy of mind

\section{INTRODUCTION: IDEALISM AND SOLIPSISM}

Ever since Descartes (at least) in the West, and for far longer in India, philosophers have entertained the possibility that the whole world is illusory, our experience of an external world merely the result of delusion. As fun as it can be to entertain this notion in films and introductory philosophy classes, however, and despite a plethora of sophisticated defenses of it in Western and Eastern philosophical traditions alike, idealism is a difficult position to genuinely and consistently subscribe to. Aside from simply being counterintuitive, one of the primary challenges to idealism is the apparent implication from idealism to solipsism. Descartes, of course, saw this. The whole point of continuing beyond the Second Meditation is to avoid solipsism:

If the objective reality of any of my ideas turns out to be so great that I am sure the same reality does not reside in me, either formally or eminently, and hence that I myself cannot

HENKEL, Jeremy E.: Assistant Professor, Department of Philosophy, Wofford College, USA. Email: henkelje@wofford.edu 
be its cause, it will necessarily follow that I am not alone in the world, but that some other thing which is the cause of this idea also exists. But if no such idea is to be found in me, I shall have no argument to convince me of the existence of anything apart from myself. (Descartes (1641/1984), p. 29; emphasis added)

I take it for granted, as did Descartes, that solipsism is an unacceptable philosophical position. In fact, if Wittgenstein's argument against private languages is correct, then solipsism is not just objectionable but actually incoherent. The Private Language Argument indicates that, if I were alone in the universe, language would be impossible and I would thus be unable to even formulate the question of whether I were alone in the universe.

If solipsism is untenable, then if it can be established that idealism leads to solipsism, it follows that idealism, too, is untenable. There are at least two reasons to believe that idealism entails solipsism. First is the problem of intersubjective agreement. If everything is mind, and all anyone can perceive is his or her own ideas, then how do you and I come to agree not only that, say, there is a tree in front of us, but even in our descriptions of that tree? A realist will press this issue because solipsism seems to be the only recourse for the idealist to respond to the problem of intersubjective agreement: "we" agree because what I take to be "you" is just another idea in my mind.

The second reason to believe that idealism entails solipsism involves the principle of parsimony. Arguments in favor of idealism typically rely on the premise that all of our experience can be explained - and indeed explained better-without reference to or reliance on an external world, and on the principle that whatever is found unnecessary in accounting for our experience ought not be posited to exist. But the principle of parsimony, in doing away with material substance, seems to be no less ruthless with other minds. My experience of the so-called external world seems to be the only basis for my belief in the existence of anything beyond myself and my perceptions. So if I can be made to doubt the existence of the physical body I see directly in front of me, then how much more dubious must be the notion of an unperceived mind that motivates that non-existent body? If I have no reason to believe in the independent existence of those objects that I perceive to lie outside my body - indeed, no reason to believe even in the existence of my body - then I have no grounds on which to justify a belief in the existence of minds, of which I have even less alleged experience. If all I can know are the modifications of my own mind, then just as the principle of parsimony demands that we eliminate material substance from our ontology once we have shown it to be unnecessary, so too does it demand that I eliminate any notion of other mind from my own ontology: one stream of subjective consciousness is enough to explain all experienced phenomena-including those that themselves are allegedly experiencing phenomena.

Neither of these concerns relies on a particular (Western or non-Western) way of framing the issue. Given the abundance of philosophers who have advocated idealism, we should expect to find that such philosophers have challenged either the view that solipsism is problematic or the view that idealism entails solipsism. The 
majority, perhaps not surprisingly, have opted for the latter. In the remainder of this essay, I will examine how Berkeley, the most prominent of early-modern idealists, and Dharmakīrti, who among Yogācārins put forward the most detailed argument for the existence of other minds, attempt to establish the co-possibility of idealism and knowledge of other minds. Beginning from quite similar arguments for the nonexistence of matter, the two philosophers employ rather different strategies for establishing the existence of other minds. This difference stems, among other things, from their responses to the problem of intersubjective agreement. Berkeley's reliance on his Cartesian inheritance allows him to account for intersubjective agreement without descending into solipsism, but it prevents him from establishing the existence of other finite minds. Dharmakīrti, in accounting for intersubjective agreement causally, is able to avoid Berkeley's limitation. But, as we will see in the conclusion of this essay, a new objection awaits Dharmakīrti. And this objection, coming as it does from a fellow idealist, proves to be much less easily dispatched. This final objection, I contend, can be useful in pointing out to idealists-Buddhist and nonBuddhist alike - an important direction to take the discussion in order to finally put down for good the solipsism objection.

\section{BERKELEY AND OTHER MINDS}

In A Treatise Concerning the Principles of Human Knowledge Berkeley argues from the empiricist premise that ideas are the only possible objects of knowledge to the conclusion that there exists no material world. His argument for idealism involves three steps. The first step is to establish that a material world, if any such world were to exist, is not a possible object of knowledge. It is the nature of ideas, according to Berkeley, to be perceived. As such, they are inert, wholly passive. But the idea of a material world is the idea of a world of objects that are capable of acting as causesas causes of our ideas of those objects, at the very least. This common-sense conception of the world is one in which our ideas resemble the objects that cause them. But common sense, according to Berkeley, is greatly mistaken, for "an idea can be like nothing but an idea" (1710/1998a, p. 105). It is as incoherent to claim that an idea can resemble a material object as it is to claim that a smell can resemble a shape - they are wholly incommensurate sorts of things. If all we can know are ideas, and if ideas cannot be of a material world, then there can be no knowledge of a material world.

The second step in Berkeley's argument for idealism involves establishing that a material world is not necessary in order to explain our seeming experience of one. He uses the classic example of "dreams, frenzies, and the like" as evidence that, while our ideas can only be caused by some sort of substance, it need not be material substance: "[I]t is possible we might be affected with all the ideas we have now, though no bodies existed without, resembling them" (Berkeley, 1710/1998a, p. 109).

The Crux of Berkeley's argument for idealism, though, is the third step, wherein

he seeks to establish that a material world is not only unnecessary but indeed incoherent. He challenges the reader: 
if you can but conceive it possible for one extended movable substance, or in general, for any one idea or anything like an idea, to exist otherwise than in a mind perceiving it, I shall readily give up the cause...I shall grant you its existence, though you cannot either give me any reason why you believe it exists, or assign any use to it when it is supposed to exist. (Berkeley, 1710/1998a, p. 110)

He explains in the next paragraph why such a challenge cannot possibly be met: meeting it would entail thinking of an object unthought-of, or conceiving of an object unconceived-of - "which is a manifest repugnancy. When we do our utmost to conceive the existence of external bodies, we are all the while only contemplating our own ideas" (Berkeley, 1710/1998a, p. 111). The incoherence of the concept of material substance being thus established, Berkeley concludes that the only rational option is to adopt idealism as our standpoint: "it remains therefore that the cause of ideas is an incorporeal active substance or spirit" (Berkeley, 1710/1998a, p. 112).

This is the point in Berkeley's argument at which the spectre of solipsism appears. The very arguments that he used to demonstrate that one can have no grounds for belief in a physical world seem also to imply that one can have no grounds for belief in any spirit - or mind - other than one's own. Berkeley argues that the notion of spirit comes from direct intuition of one's own status as experiencer. In his Three Dialogues Between Hylas and Philonous Berkeley explains how it is that we can be aware of the existence of spirit despite the impossibility of a corresponding idea. Speaking in the voice of Philonous, in the Third Dialogue he makes the point that perception - which gives rise to ideas - is just one of the three permissible grounds for belief (Berkeley, 1713/1998a, pp. 115-117). We can defensibly believe in something of which we have no idea if we have a direct intuition of that thing or if the existence of that thing is a necessary presupposition for or consequence of something that we do know (that is, if it can be directly experienced or logically inferred from direct experience). Spirit is thus rendered unproblematic, as every idea we experience carries with it a direct intuition of the spirit that is the experiencer of that idea. Awareness of one's own mind, coming as it does through direct intuition, cannot be called knowledge because it does not lead to an idea of mind; it does, however, lead to what Berkeley calls a notion of mind. ${ }^{1}$ But, since we do not have direct intuition of other spirits, belief in the existence of other minds seems to be no more justified than belief in the physical world. Berkeley's solution to this problem is that belief in other minds can be justified through inference.

In the beginning of the Treatise Berkeley states that ideas can arise through senseexperience, the passions, or imagination (including memory) (1710/1998a, p. 103). His inference to the existence of other minds begins from the recognition that our experiences of the different sorts of ideas are themselves qualitatively different.

\footnotetext{
${ }^{1}$ Berkeley's insistence that awareness of one's own mind is not knowledge is interestingly similar to Wittgenstein’s dictum in the Philosophical Investigations (\$246) that knowledge of one’s own pain makes no sense - that such a claim betrays a failure to understand what we normally mean in our use of the word 'knowledge'. 'Knowledge' makes sense only within the context of the possibility for error.
} 
Whereas the ideas of memory and imagination that I experience are wholly subject to my will, my sense-experiences are not similarly compliant:

But whatever power I may have over my own thoughts, I find the ideas actually perceived by sense have not a like dependence on my will. When in broad daylight I open my eyes, it is not in my power to choose whether I shall see or not, or to determine what particular objects shall present themselves to my view; and so likewise as to the hearing and other senses, the ideas imprinted on them are not creatures of my will. There is therefore some other will or spirit that produces them. (Berkeley, 1710/1998a, 113)

My experience of ideas that do not find their cause in my mind is not, for Berkeley, a refutation of the thesis that all ideas have their origin in mind (and so a rejection of idealism); rather, it is a confirmation that mine is not the only mind. While I have no direct intuition of others' minds, I do have sense-experience of actions that reveal the workings of a mind, which themselves form the basis of a valid inference to the existence of a mind as the volition behind the action. My further recognition that these volitional actions are not subject to my own will reveals to me the existence of a will other than my own. I thus come by my notion of other mind in addition to my notion of my own mind. ${ }^{2}$ As Anita Avramides points out, despite many commentators' arguments to the contrary, this is not an argument by analogy a la Mill. Rather, this is a causal argument, taking the following form:

P1: All ideas are caused by some mind.

P2: I experience ideas that are independent of my will.

P3: Ideas that are independent of my will must be caused by a mind other than my own.

C1: Therefore, a mind other than my own exists.

Having thus explained the difference between our different sorts of ideas, Berkeley is in a position to address the realist's concern regarding intersubjective agreement. Given the passivity of perception-as opposed to the activity of imagination - it makes sense that other people too will find their ideas of sense to be independent of their will. Ideas of sense thus being imposed on our experience, it is not surprising that different people's reports of sense-experience agree with one another in a way that their reports of those mental states that are subject to an individual's will do not. But given the conclusion, already established by this point, that all ideas are caused by mind, Berkeley must give an account of the sort of mind

\footnotetext{
${ }^{2}$ Cf. Also what he says in paragraph 145 (1710/1998a, p. 157). Berkeley is subject to a biting criticism here: what if, in considering my ideas to be unchosen by my will, I have deceived myself? The paradigm case of this is, of course, dreams, but one could argue that addicts deceive themselves when they claim that their cravings come unbidden. It is interesting to note that, though he twice mentions dreams (paragraphs 18 and 42) in support of his idealist thesis, Berkeley does not seem to have considered the possibility that dreams could pose a counterexample, calling into question the validity of this inference. I will more fully examine the dream objection below, in the context of Dharmakirti's response to it.
} 
that would be necessary to explain the seemingly independent existence of senseideas. Clearly, the mind that is the source of such ideas must be qualitatively different from a human mind. The ideas of imagination that people experience

are faint, weak, and unsteady in respect of others they perceive by sense, which being impressed upon them according to certain rules or laws of nature, speak themselves the effects of a mind more powerful and wise than human spirits. (Berkeley, 1710/1998a, p. 115)

For Berkeley, then, intersubjective agreement and the stability of an individual's sense-ideas are intertwined-and neither presents a difficulty that the idealist cannot respond to. Our sense-ideas are stable and a matter of intersubjective agreement because our ideas of sense are caused by God: an infinite mind that keeps everything in existence by being a perpetual perceiver.

To summarize: for Berkeley, intersubjective agreement blocks the inference from idealism to solipsism, rather than demanding it. Intersubjective agreement is a result of our sense ideas being more stable than our imagination-based ideas, and this itself is a result of the existence of a qualitatively different mind. The principle of parsimony thus does not demand an inference from idealism to solipsism. Once it has done away with the material world, it in fact demands the existence of another mind to explain our experiences: the mind of God.

At this point Berkeley is subject to a critical objection: insofar as he succeeds at proving the existence of God, he seems to eliminate any reason for believing in other finite minds. With God as a sufficient cause of all my ideas, I no longer find myself in a position to infer distinct individual minds motivating the representations I have of my spouse and my child - both are merely aspects of God's universal mind. ${ }^{3}$ If this objection succeeds, then Berkeley may have avoided solipsism, but with the result of existing alone in the universe with God. Such a prospect is little, if at all, more appealing than solipsism.

Berkeley's reply to this objection calls to mind Descartes. It is the uniformity of experience, he points out, that makes the benefit — and even the maintenance — of life possible: "And without this we should be eternally at a loss: we could not know how to act anything that might procure us the least pleasure, or remove the least pain of sense" (Berkeley, 1710/1998a, p. 113). The intra- and interpersonal regularity of sense-ideas, which are not subject to one's own will, Berkeley takes to be a mark of the benevolence of the will that is their author. And once we can be confident in the existence of a benevolent God, we have no reason to assume that our belief in other minds is a result of deception.

But it is not at all clear that this response does succeed. Berkeley is correct that the regularity of experience is a necessary condition for the maintenance of life, but from this we cannot infer a benevolent God at all: all Berkeley is justified in inferring from the stability of our sense-ideas is a mind that wants us to have experience that is

\footnotetext{
${ }^{3}$ This objection is posed by Jonathan Bennett. Avramides (2001, p. 125-130) makes considerable use of it in her explication of Berkeley, and I am following her analysis.
} 
coherently enough ordered to be called experience at all. But since the author of our sense-ideas could well have the maximization of pain and misery as a goal, this could be a mark of malevolence just as easily as it could be of benevolence. All we need to do to see the truth of this is to consider the case of torture. On the assumption that one's purpose is to maximize the pain and suffering of another, the primary objective must be to keep that person alive and lucid enough to experience suffering. And cultivating in that person a belief in the existence of loved ones, who themselves can seem to suffer or cause suffering in the subject through various other means, is certainly a powerful tool for increasing the experience of suffering.

Berkeley's argument for the existence of other finite minds hinges on the ability to infer God's benevolence from the orderliness of one's experience. This inference fails. Thus Berkeley seems to be unwittingly committed, if not to solipsism, then to the belief that in addition to oneself only God exists. His contention (1710/1998a, p. 158) that we have even greater ground for belief in God than in the existence of other finite minds is thus true, but in a way that he never intended.

The medieval Buddhist philosopher Dharmakīrti is as concerned as Berkeley is to show that idealism does not entail solipsism. Dharmakirti's response to the problem of intersubjective agreement differs markedly from Berkeley's, however; this difference saves him from the concerns that plague Berkeley's account. Let us turn now to Dharmakīrti's arguments.

\section{DHARMAKIRTI AND OTHER STREAMS OF CONSCIOUSNESS}

As a member of the Yogācāra school of Buddhism, Dharmakīrti inherits arguments for idealism that are similar to the arguments we have already seen from Berkeley. Vasubandhu's Twenty Verses (Vimśatikā), for instance, makes use of dreams and cases of perceptual error (eye-diseases, illusions) to show that all our experiences can be explained without reference to physical causes. Among Dharmakīrti's unique contributions is the argument from constant co-cognition (sahopalambhaniyama), which anticipates by more than a millenium Berkeley's argument for idealism. In the Pramānavārttika Dharmakīrti points out that, for any two objects, if they are distinct then they will be available in isolation from one another. But blue, for instance, is never found in isolation from awareness of blue. It follows, then, that blue and awareness of blue are non-distinct. Since the same deduction can be made with regard to any object or property - a pot is never found distinct from awareness of the pot, heat is never found distinct from awareness of heat, etc.-we are left to conclude that the world consists in nothing more than various states of awareness. Anything that I take to be an external object is nothing more than my mental state.

Dharmakìrti's argument for idealism, then, is quite similar to Berkeley's argument for the incoherence of extended matter. But despite the similarity in starting points, Dharmakīrti's idealism takes on a significantly different feel from Berkeley's. In his Proof of the Existence of Other Streams of Consciousness (Santānāntarasiddhi; hereafter Proof), Dharmakīrti provides what is perhaps still the most extensive argument that idealism does not imply solipsism that has yet been advanced. He 
argues for an inference to the existence of other streams of consciousness ${ }^{4}$ that is similar to what Berkeley advocates, but he stops short of concluding the existence of God. Instead he provides a causal account of intersubjective agreement that is unlike anything we find in Berkeley. In this section I will argue that this move saves Dharmakīrti from Berkeley's fate and thus, if his inference to other streams of consciousness works, then Dharmakirti shows idealism not to lead to solipsism in a more tenable way than does Berkeley.

Much of Dharmakīrti's argument amounts to demonstrating that knowledge of other streams of consciousness is no more problematic for the idealist than for the realist because they use the same method. The realist will agree with the idealist that we have no direct perception (pratyakșa) of others' mental states, and thus that any knowledge we can have must come by means of inference (anumāna). The realist, believing that extended objects exist in an external world, infers the existence of the mental from physical evidence. The only difference from this account for the idealist is that idealists understand the evidence to be a mental representation of a physical act, rather than the physical act itself. But, Dharmakīrti points out, this does not indicate a difference at all, because the realist makes precisely the same inference: idealists and realists alike infer the existence of other minds from mental representations of actions, not from actions themselves. To prove this, he asks whether we come to cognize another's consciousness from the mere existence of action, or only from the actual perception of that action. Clearly the mere existence is not sufficient, otherwise everyone would have knowledge of all other consciousnesses. Thus the inference is not from the action, but from one's perception - that is, mental representation - of actions and speech. We only know that our mental representations are caused by another consciousness; we can say nothing about acts in themselves (Dharmakīrti, 1969, Verses 40-47).

For Dharmakīrti, then, idealism does not entail solipsism any more than realism entails solipsism: both the idealist and the realist infer the existence of other streams of consciousness from the experience of volitional actions that do not originate within one's own stream of consciousness. It remains to establish exactly how, according to Dharmakīrti, that inference proceeds. He says that all volitional actions-such as speech and other movements that reveal intentionality-have their origin in consciousness. Those volitional actions that I experience subjectively as originating from within provide a confirmation of this: my actions reveal my intentions, and my lack of action reveals a corresponding lack of intention. The subjectively-experienced actions also provide an example of how volitional actions manifest, which helps me to recognize those volitional actions that I experience objectively (that is, as

\footnotetext{
${ }^{4}$ Being a Buddhist, Dharmakīrti of course does not believe in the existence of "minds" per se. In denying the existence of the atman, the Buddhist denies that there is an irreducible subject of experience that has privileged epistemic status-something that Berkeley, due to his Cartesian inheritance, takes for granted. Nevertheless, what Berkeley wants to call "mind, spirit, soul, or my self" the Buddhist will call a "santāna" or "stream of consciousness", thereby acknowledging the perceived unity of an individual life while denying any unchanging substance that underlies this perceived unity.
} 
originating from without) as volitional, despite the phenomenological difference in how they are experienced.

The difference between subjectively and objectively experienced volitional actions amounts to a difference between experience and non-experience of the causally efficacious mental states that lead to the action. Objectively experienced volitional actions are those that I cannot find the cause of within my own stream of consciousness. Knowing that if they had their cause within me I would be aware of it, I conclude that such actions have their cause outside my own consciousness. Having established that all volitional actions are similar in having their origin in consciousness, and that objectively-experienced volitional actions differ from subjectively-experienced ones by virtue of not having their origin in my consciousness, the conclusion follows that objectively-experienced volitional actions have their origin in another consciousness-which means, of course, that another consciousness exists. Thus, Dharmakīrti concludes, the idealist is able to infer the existence of other streams of consciousness: "Between the concept of mind in general and that of its external manifestations in movements and speech, there is a causal relation, and on the basis of the effect, we shall cognize the cause" (1969, Verse 48).

Dharmakīrti's argument for the existence of other streams of consciousness, then, takes the following form:

P4: I experience actions of a certain type. ${ }^{5}$

P5: Actions of this certain type have their cause in consciousness.

P6: These actions do not have their cause in my consciousness.

C2: Therefore, these actions have their cause in another consciousness.

C3: Therefore, consciousnesses other than mine exist.

Like Berkeley, Dharmakīrti argues that awareness of other minds can be justified through logical implication. However, Dharmakīrti would not agree with Berkeley that the differences between our sense-ideas and our other ideas-which differences explain the phenomenon of intersubjective agreement-give proof of a qualitatively different sort of consciousness as their cause. Instead, Dharmakīrti shows that intersubjective agreement can be explained causally even among a community of finite minds. People's reports of the "external world" agree because they have similar causal histories and similar perceptual mechanisms. In any circumstance, given (nearly) identical causes, one would expect (nearly) identical effects. So if the causal explanation for my perception of the tree is the same as that for your perception of the tree, then it should come as no surprise that our experiences of that tree are themselves similar. And this is true for the realist just as much as for the idealist. Someone in Istanbul and someone in Tokyo cannot directly experience the same

\footnotetext{
5 I use the word 'type' here advisedly, as Dharmakīrti's denial that sāmānyalakșanas are ultimately real (because not causally efficacious) precludes him ascribing any substantial reality to types. But his apoha theory does, I take it, provide him with the tools necessary to make sense of a differentiation between actions that reveal volition and those that do not. (I thank the anonymous reviewer of this journal for encouraging me to be clearer on this point.)
} 
tree - at least, not at the same time - and this because of their distinct causal histories, which have led them to be in vastly different locations. However, a person and a bat, if they were somehow able to communicate with one another, would be highly unlikely to agree in their descriptions of a tree they were both in proximity of because of the differences between each's perceptual apparatus. Indeed, it does not seem absurd here to suggest that they may not be experiencing the same tree at all.

Dharmakirti insists that we need not posit the existence of the object experienced in order to account for intersubjective agreement. To make his point, he uses the example of two people with the same eye condition, both of whom think they see two moons. Their agreement in experience is not caused by an object that corresponds to and causes their experience, but by the agreement of the causal factors in their perception. This illustrates that there need be no external object causing the experiences in order for the experiencers to agree in their reports of their individual experiences (Dharmakīrti, 1969, Verse 65). By explaining intersubjective agreement without appeal to a consciousness that is qualitatively different from human consciousness, Dharmakīrti avoids the conclusion that Berkeley could not: that one is alone in the universe with God.

An important objection can be raised against Dharmakīti here, however. The example he uses, it seems, does not succeed, because even here the erroneous perception is caused not just by the faulty eyes, but also by the materially existent moon. The only proper analogy we have to what experience would be like without external objects to regulate it, the objection continues, is our experience of dreams. But in dreams there is no agreement between experiencers. One's dream experiences are one's own; within the dream there is no other experiencer, and once outside the dream one finds that nobody else's experience agrees with the experience one had within that dream. This objection seems to strike right to the heart of Dharmakīrti's argument, not just regarding intersubjective agreement but regarding the inference to other streams of consciousness at all: for if all our waking experience is akin to our dream experiences, then inferring the existence of other consciousness from the appearance of volitional action seems highly dubious. In dreams I frequently experience the representations of volitional actions that seem to have their source outside me. But subsequent waking experience informs me that my original assessment was incorrect, that those experiences were the result of no consciousness other than my own. And if it is possible to experience representations of a volitional action as caused by a consciousness other than my own when they are in fact caused by my own, then in no instance am I justified in inferring the existence of another consciousness merely from such a representation. But since the idealist cannot provide another account, we must conclude that idealism does in fact commit one to solipsism.

Dharmakìrti is well aware of the dream objection. In fact, the bulk of the Proof is dedicated to refuting it. His response begins by pointing out that the realist's account of dreams is no less problematic than is the idealist's. If, as according to the realist, objectively experienced volitional actions within a dream do not provide a valid ground for inferring other consciousnesses, then neither do they in waking life. Such 
an inference can be legitimate only if it is valid universally; if dream-experiences block the inference, then we can no longer say that objectively experienced volitional actions are a consistent mark of the existence of other minds - in the parlance of Indian logic, pervasion (vyapti) is lost. We are thus, according to this argument, never justified in inferring the existence of another mind from objectively experienced volitional actions, even when we are awake (Dharmakīti, 1969, Verses 53-58). Dharmakīrti provides a ready response to this concern-one that is available to the realist and the idealist alike. He points out that the inference to another consciousness that occurs within a dream is valid within the dream (Dharmakīti, 1969, Verses 8387). The error arises if, after we wake up, we try to carry the inference over into the waking world. For Dharmakīti, the best criterion we can have for the truth of a cognition (jĩ $\bar{a} n a)$ is successful action. The actual existence of the object inferred is thus not a necessary (or, given his idealist leanings, even a possible) condition for the validity of an inference. The question is, rather, whether actions that are based on that inference meet with success or with frustration. Given that the inferences to the existence of other streams of consciousness that we make within our dreams do lead to successful action within said dreams, the dream-inference must be taken as valid:

Those inferences of other mind which are made in sleep are possible only in such a state; exactly thus, the attainment of aim - the conversations, etc - which take place in sleep, are [also] possible only at this time. But since at this time is possible such an activity as is not contradictory, has mutual bond and is logical, there is no inconsistency in our theory. (Dharmakīrti, 1969, Verse 87 Commentary)

Since the inference leads to successful activity, it would be absurd to insist that we have no dream-experience of other consciousness simply because the marks by which we infer such consciousness are not present in waking experience. Given our successful ability to navigate the social world when awake, it is similarly absurd to say that we have no waking experience of other consciousness simply because the marks of other consciousness do not exist in the manner the realist thinks they do.

Dharmakīrti provides another, more obscure response to the dream objection as well. In Verse 51 he says,

In [cases of] illusions, the course of our representations is under the influence of special causes, the nature of which determines the content of the representations. The representations may also be caused by other mind and [various] other factors, in which case there is sometimes an interruption in time between these factors and the representations; but these representations cannot appear quite independently of them.

This passage is difficult to interpret, and Vinītadeva's gloss does little to clarify, but one possibility is that Dharmakirti is making the point that the mere existence of dreams presupposes objective experience, on which dreams are based. On this reading the dream-representations I experience of volitional action, while directly dependent on only my mental states, are indirectly dependent on the mental states of others-because the possibility of my presently having mental states that represent 
another's volitional action is dependent on my having antecedently had actual experience of such cases. This seems to be a plausible point for Dharmakirti to make. Some support for the position can be found in studies that have indicated that congenitally blind people have sightless dreams, though they experience other dreamsensations just as much as sighted people do (Kerr and Domhoff, 2004).

These two responses, taken together, I think are sufficient to undermine the dream objection. But other objections remain-objections to which Dharmakīrti provides less thorough responses. One that strikes me as particularly powerful is this: if the goal of an inference is to prove that a particular event has its origin in consciousness, then by asserting that the event in question is a volitional act is Dharmakīrti begging the question? After all, if he has defined volitional actions as those having their origin in consciousness, then for any event under consideration it should begin as an open question whether that event is a volitional action. Throughout the Proof, speech is taken to be an inferential mark of consciousness. But a bird that can imitate human speech is not taken to be expressing the mental state that we would take such speech to indicate if uttered by a human. Why, then, assume that people's speech indicates volition?

There is an easy response to this objection, which likely explains why Dharmakīrti did not bother considering the objection at all. Given the idealist thesis, everything that we experience either has its cause in consciousness or is uncaused. But on the Buddhist metaphysical framework, nothing is uncaused. It follows that everything has its cause in consciousness. The only question, then, is whether the consciousness that is originary to this particular event is one's own. But that is what this whole inquiry aims to answer, and thus there is no logical flaw in beginning from this starting point.

This response, however, seems insufficient because it overlooks some of the underlying concerns behind the objection. Particularly, it does not answer the question of why we do not take the bird that mimics human speech to be expressing a volition, but we do take people to. (Note that we take the bird to be mimicking human speech, not speaking.) Relatedly, we sometimes do not hold people to be responsible for their speech and actions: how do we justify such an inconsistency in our attributions? How do I really know whether a person's volitional actions have their origin in her consciousness? Fortunately, even though Dharmakīrti does not respond to my concern about question-begging directly, he does address the concerns that motivate it.

To begin with, his Verse 51 response to the dream objection and his later response to the challenge that inference to other consciousness is not pramāna (Dharmakīrti, 1969, Verses 66-72) remind us of the Buddhist success-criterion for truth. Starting from the assumption that what I experience as speech emanating from another reveals a consciousness within that other as cause of that speech, my ensuing activity will meet with either success or frustration, depending on the circumstance. Attempting to engage a bird in discussion meets with much more frustration than success, and ultimately leads me to recognize the falsity of the initial assumption. But the attempt to engage people in discussion, in response to what I experience as their speech, 
generally meets with success (and, where frustration, frustration of a different sort). The bird's speech we can still recognize as a mark of consciousness, however. Only, it is not the bird's consciousness but rather the consciousness of the individual who originally spoke the words that the bird is now parroting. This example demonstrates Dharmakīrti's point that a volition and the actions that result from that volition need not be co-locational. If I throw a stone, for instance, the flight of the stone is an intentional act, but one that has its origin in my consciousness. Similarly if someone pushes me down a flight of stairs, then my movement is the result of an intentional state-but not my own (Dharmakīrti, 1969, Verse 18). Thus we can see that a person is taken to be responsible for her actions if the conscious will that gave rise to the action is her own as well- that is, if she experiences the act subjectively.

The objection is not so easily put to rest, however. R. K. Sharma has argued that, rather than reinforcing the inference to other minds as Dharmakīti thinks it does, this admission actually renders impossible any such inference: "The invariable relation between consciousness and bodily behaviour now stands eviscerated of all such subjective conviction on which rested analogical reasoning, with the result that even the certainty of this relation now comes under question" (Sharma 1985, 59). In order to infer, by means of an analogy, your intentional state from your actions, I must already have established that my actions are always accompanied by my mental states. But if my actions can be the result of another's will, then the universal association of my action with my willing does not obtain-and thus there is no ground for the analogy. Sharma's challenge, then, is similar to Dharmakîrti's challenge regarding the realist's account of dreams: with pervasion lost, the inference is undermined.

I noted above that Berkeley has been incorrectly interpreted as providing an argument by analogy to support the inference to other minds. I suspect Sharma is similarly misreading Dharmakirti. To illustrate this, consider the structure of an argument for the existence of other minds by means of an analogy:

Argument by Analogy:

P7: My actions of a certain type have their cause in my consciousness

P8: These actions are of that certain type

P9: These actions do not have their cause in my consciousness

C4: Therefore, these actions have their cause in another consciousness

C5: Therefore, consciousnesses other than my own exist

And compare this with Dharmakīti's Argument for the existence of other streams of consciousness, as articulated above:

P4: I experience actions of a certain type.

P5: Actions of this certain type have their cause in consciousness.

P6: These actions do not have their cause in my consciousness.

C2: Therefore, these actions have their cause in another consciousness.

C3: Therefore, consciousnesses other than mine exist. 
Given the similarity of the final conclusions, as well as the third premise, in the two arguments, it is understandable how Dharmakīrti could be read as providing an analogical argument. But from the differences between the first two premises of each argument, it should be clear that Dharmakīrti is not advocating an analogy. Dharmakīrti's causal argument can best be understood, rather, as an argument by remainder.

What Sharma has provided, I think, is an insightful critique of the possibility of establishing the existence of other minds by means of an analogy. But as a critique of Dharmakīrti it misses its mark. Rather than providing a reductio of Dharmakīrti's argument, Sharma provides a reductio of his own claim that Dharmakirti makes use of an argument by analogy. The argument by analogy relies on an action's being similar to mine in order for me to infer a similar cause. But if it can be shown that there is a difference between my own actions and the actions that form the basis of the inference, then the analogy will be undermined. The argument by remainder, on the other hand, relies on a property of actions generally, and applies that property to the two cases separately. In this way, differences between the two cases under consideration do not undermine the inference as long as the cases still fall under the type. Whereas the argument by analogy takes one's own actions to be the paradigm, the argument by remainder takes actions generally to be the paradigm, and recognizes that one's own actions are merely a type that fall under that general category.

\section{CONCLUSION}

Dharmakīrti's argument for knowledge of other streams of consciousness succeeds in showing the realist's objections to be incapable of refuting the idealist's thesis. For each objection the realist brings to bear, the idealist is able to show that his theory accounts for experience as well as or better than the realist's theory. There remains an objection from another camp, however, that is more difficult to respond to: the fellow idealist. Ratnakīrti, a successor of Dharmakīrti, argues that the idealist ought to embrace solipsism. Ratnakīrti accepts Dharmakīrti's argument from constant colocation in a way the realist cannot bring himself to. But he then proceeds to use this argument against Dharmakirti's inference to other streams of consciousness. Just as blue and my awareness of blue are non-distinct, so too are your consciousness and my awareness of your consciousness. The idea of your mental states existing independent of my awareness of those mental states is unthinkable by me, in precisely the way that Berkeley points out that it is impossible to think of an object unthought-of. Within my experience there is no difference between your feeling, say, angry, and my representing to myself that you are angry. This being the case, what possible meaning can asserting knowledge of other streams of consciousness have for me, beyond being an assertion about my own consciousness - and thus not about other streams of consciousness after all?

This seems to me an exceedingly difficult challenge for Dharmakīti to respond to. One possibility is that he could abandon his own argument for idealism, and make use instead of Vasubandhu's and Dignāga's arguments (though these are not without 
their own detractors). As Arindam Chakrabarti (1990) points out, there exist a number of sophisticated responses to the argument from constant co-location.

A less unpalatable response for Dharmakīti may be to claim that the inference to other streams of consciousness provides content for the assertion that not all of my states of awareness are up to me. This may reduce ultimately to an assertion about my own mental states, but it is a different sort of assertion about my mental states - that they have their cause in something outside me, something that is beyond the grasp of perceptual awareness, and only indirectly within the grasp of inferential awareness. I take this approach to be the most promising way not just for Dharmakīrti, but for idealists more generally to respond to Ratnakīti's objection. This is important because, while the objection itself may originate in medieval India, it is relevant to anyone who wants to advocate idealism, regardless of temporal or geographic circumstance.

There is a caveat attached to this move, however: it brings one dangerously close to Berkeley's position of inferring a qualitatively different sort of mind, the position that led him to the consequence that Dharmakīrti's idealism has heretofore been able to avoid. But if the idealist remains faithful to Dharmakirti's causal account of experience and of intersubjective agreement, and does not concern herself overmuch with the nature of the mental cause that is just beyond one's grasp, she may be able to avoid the untoward consequence.

\section{ACKNOWLEDGMENTS}

I presented a version of this paper at a meeting of the International Society for Chinese Philosophy in conjunction with the 2007 APA Pacific Division meeting. Thank you to the audience members and other panelists for your comments. Thank you also to Arindam Chakrabarti for providing extensive feedback on an earlier version of this paper, and to the three anonymous referees for this journal whose helpful comments enabled me to become clearer in my argument and improve the article overall.

\section{REFERENCES}

Avramides, Anita (2001), Other Minds (London: Routledge).

Bennett, Jonathan (1971), Locke, Berkeley, Hume: Central Themes (Oxford: Clarendon Press).

Berkeley, George (1998a), A Treatise Concerning the Principles of Human Knowledge, Jonathan Dancy (ed.), (Oxford: Oxford University Press).

Berkeley, George (1998b), Three Dialogues Between Hylas and Philonous Jonathan Dancy (ed.), (Oxford: Oxford University Press). 
Burnyeat, Myles (1982), "Idealism and Greek Philosophy: What Descartes saw and Berkeley Missed", The Philosophical Review, 91 (1): 3-40.

Chakrabarti, Arindam (1990), "On the Purported Inseparability of Blue and the Awareness of Blue: An Examination of Sahopalambhaniyama", in Doboom Tulku (ed.), Mind Only School and Buddhist Logic (New Delhi: Tibet House), 1736.

Descartes, René (1641), Meditations on First Philosophy; trans. J. Cottingham, R. Stoothoff, and D. Murdoch (1984) The Philosophical Writings of Descartes (Cambridge: Cambridge University Press).

Dharmakīrti, Santānāntarasiddhi with Vinītadeva's commentary; trans Harish C. Gupta, in Debiprasad Chattopadhyaya (ed) (1969), Papers of Th. Stcherbatsky: Translated for the First Time Into English (Calcutta: Indian Studies Past and Present), 84-121.

Kerr, Nancy and G. William Domhoff (2004), "Do the blind literally 'see' in their dreams? A critique of a recent claim that they do", Dreaming, 14: 230-233.

Sharma, Ramesh Kumar (1985), "Dharmakīrti on Other Minds", Journal of Indian Philosophy 13: 55-71.

Vasubandhu, Vimśatikā; trans. Stefan Anacker (1984), in Seven Works of Vasubandhu, the Buddhist Psychological Doctor (Delhi: Motilal Banarsidass), 157-190.

Wittgenstein, Ludwig (1953), Philosophical Investigations; trans. G.E.M. Anscombe $\left(3^{\text {rd }}\right.$ ed., 2001) (Oxford: Blackwell). 